\title{
INSECT FOOD HABIT RATIOS ON QUELPART ISLAND $^{1}$
}

\author{
By Harry B. Werss. \\ New Brunswick, N. J.
}

The following notes represent an attempt to reduce the activities of the insects on Quelpart Island to certain food-habit types and to express the relative importance of these types in terms of parts of the whole, thus establishing a series of ratios. A list of the insects of this island was published recently by Hanjiro Okamoto as Volume 1, No. 2, Bulletin of the Agricultural Experiment Station, Government-General of Chosen, Suigen, Corea, Japan, March, 1924, and the species in this list were arranged and tabulated in accordance with the predominating larval habits of their families.

According to Mr. Okamoto, Quelpart Island is the most southern point in Corea, being the largest island adjacent to that part of the mainland. Its total area is given as about 718 square miles. The highest point is Mt. Kanra with an elevation of $2056 \mathrm{~m}$., and the island consists mainly of tertiary volcanic peaks surrounding Mt. Kanra with a gradual slope to the sea. Mr. Okamoto quotes Dr. Nakai concerning the native plants which number about 1300 species and it is possible to separate the island into seven zones, "of which the southern limit of each is much higher in elevation than the northern, except at the top, where no relation exists with respect to the ocean current, and the seventh zone is consequently level on all sides." The flora of the four lower zones is temperate while a more northern flora is found in the three upper ones. The island therefore has a flora of a wide range. A more detailed description of the area can be found in Mr. Okamoto's paper.

Some 527 species are listed and although this figure does not represent a "complete count," from the information given as to the routes and times of the collecting trips, it does appear as if it might be considered as a representative sample. Even

${ }^{1}$ Former papers on the ratios of insect food habits were published in the Ohio Journal of Science, vol. xxiv, pp. I00-I06, Entomological News, vol. xxxv, pp. 362-364 and the Proceedings of the Biological Society of Washington, vol. 38 , pp. I-4. 
though not strictly representative, it is the nearest approach to it that is available at this time.

In accordance with their family food habits, the 527 species can be grouped approximately as follows:

\begin{tabular}{l|c|c|c|c|c|c}
\hline \hline & $\begin{array}{c}\text { No. } \\
\text { species }\end{array}$ & $\begin{array}{c}\text { Phyto- } \\
\text { phagous. }\end{array}$ & $\begin{array}{c}\text { Sapro- } \\
\text { phagous }\end{array}$ & $\begin{array}{c}\text { Harpac- } \\
\text { to- } \\
\text { phagous }\end{array}$ & Parasitic & $\begin{array}{c}\text { Pollen } \\
\text { feeders, } \\
\text { misc. sp. }\end{array}$ \\
\hline Quelpart Island & 527 & $60 \%$ & $16 \%$ & $20.8 \%$ & $\mathbf{1 . 5 \%}$ & $\mathbf{1 . 7 \%}$ \\
\hline
\end{tabular}

A comparison of the above ratios with the ratios for other sections which have been collected over more thoroughly and which have been treated in a similar way, shows that the parasitic figure for Quelpart Island is too low, due to the fact that the parasitic Hymenoptera are not represented as they should be. From studies of "samples" in other areas, it appears that the parasitic figure should be about 10 and in view of this, 50 species have been provisionally added to the parasitic group making the total number of species 577 and resulting in the adjusted set of ratios found below.

\begin{tabular}{l|c|c|c|c|c|c}
\hline & $\begin{array}{c}\text { No. } \\
\text { species }\end{array}$ & $\begin{array}{c}\text { Phyto- } \\
\text { phagous }\end{array}$ & $\begin{array}{c}\text { Sapro- } \\
\text { phagous }\end{array}$ & $\begin{array}{c}\text { Harpac- } \\
\text { to- } \\
\text { phagous }\end{array}$ & Parasitic & $\begin{array}{c}\text { Pollen } \\
\text { feeders, } \\
\text { misc. sp. }\end{array}$ \\
\hline Quelpart Island & 577 & $55 \%$ & $15 \%$ & $19 \%$ & $10 \%$ & I\% \\
\hline
\end{tabular}

It is now possible to compare these ratios with those of other areas and this has been done in the following table I. It will be noted that the figures in each column do not differ widely and suggest a fixed relationship or at least a close resemblance. The same relationships are brought out in a slightly different manner in table II wherein the comparisons are made with the parasitic food habit as a base. For example, if the adjusted parasitic food habit in Quelpart Island is represented by 1, then the relative importance of the other types is, phytophagous 5.5 , saprophagous 1.5 , etc. 
TABI.E I

\begin{tabular}{l|c|c|c|c|c|c}
\hline & $\begin{array}{c}\text { No. } \\
\text { species }\end{array}$ & $\begin{array}{c}\text { Phyto- } \\
\text { phagous }\end{array}$ & $\begin{array}{c}\text { Sapro- } \\
\text { phagous }\end{array}$ & $\begin{array}{c}\text { Harpac- } \\
\text { to- } \\
\text { phagous }\end{array}$ & Parasitic & $\begin{array}{c}\text { Pollen } \\
\text { feeders, } \\
\text { misc. sp. }\end{array}$ \\
\hline Quelpart Island & 577 & $55 \%$ & $\mathrm{I} 5 \%$ & $\mathrm{I} 9 \%$ & $\mathrm{10} \%$ & $\mathrm{I} \%$ \\
\hline $\begin{array}{l}\text { Western Arctic } \\
\text { Coast of N. A. }\end{array}$ & 400 & $47 \%$ & $27 \%$ & $\mathrm{I} 4 \%$ & $\mathrm{I0} \%$ & $2 \%$ \\
\hline State of N. J. & $\mathrm{I0,500}$ & $49 \%$ & $\mathrm{I} 9 \%$ & $\mathrm{I} 6 \%$ & $\mathrm{I} 2 \%$ & $4 \%$ \\
\hline State of Conn. & $6,78 \mathrm{I}$ & $52 \%$ & $\mathrm{I} 9 \%$ & $\mathrm{I} 6 \%$ & $\mathrm{I0} \%$ & $3 \%$ \\
\hline
\end{tabular}

TABLE II

\begin{tabular}{l|r|r|r|r|r|r}
\hline Quelpart Island & 577 & $5.5 \%$ & $\mathrm{I} .5 \%$ & $\mathrm{I} .9 \%$ & $\mathrm{I} .0 \%$ & $\mathbf{0 . 1 0 \%}$ \\
\hline $\begin{array}{l}\text { Western Arctic } \\
\text { Coast of N. A. }\end{array}$ & 400 & $4.7 \%$ & $2.7 \%$ & $\mathrm{I} .4 \%$ & $\mathrm{I} .0 \%$ & $0.20 \%$ \\
\hline State of N. J. & $\mathrm{I} 0,500$ & $4 . \mathrm{1} \%$ & $\mathrm{I} .6 \%$ & $\mathrm{I} .3 \%$ & $\mathrm{I} .0 \%$ & $0.33 \%$ \\
\hline State of Conn. & $6,78 \mathrm{I}$ & $5.2 \%$ & $\mathrm{I} .9 \%$ & $\mathrm{I} .6 \%$ & $\mathrm{I} .0 \%$ & $0.30 \%$ \\
\hline
\end{tabular}

The adjusted figures for Quelpart Island, with its varied flora, tend to support the suggestion advanced in previous papers, that the ratios between the various types of food habits, based on the species present, vary but little when large areas, each embodying different types of vegetation are considered in toto and when the numerical ratios between the species present and the factors tending to reduce or change their numbers are considered as constant. 

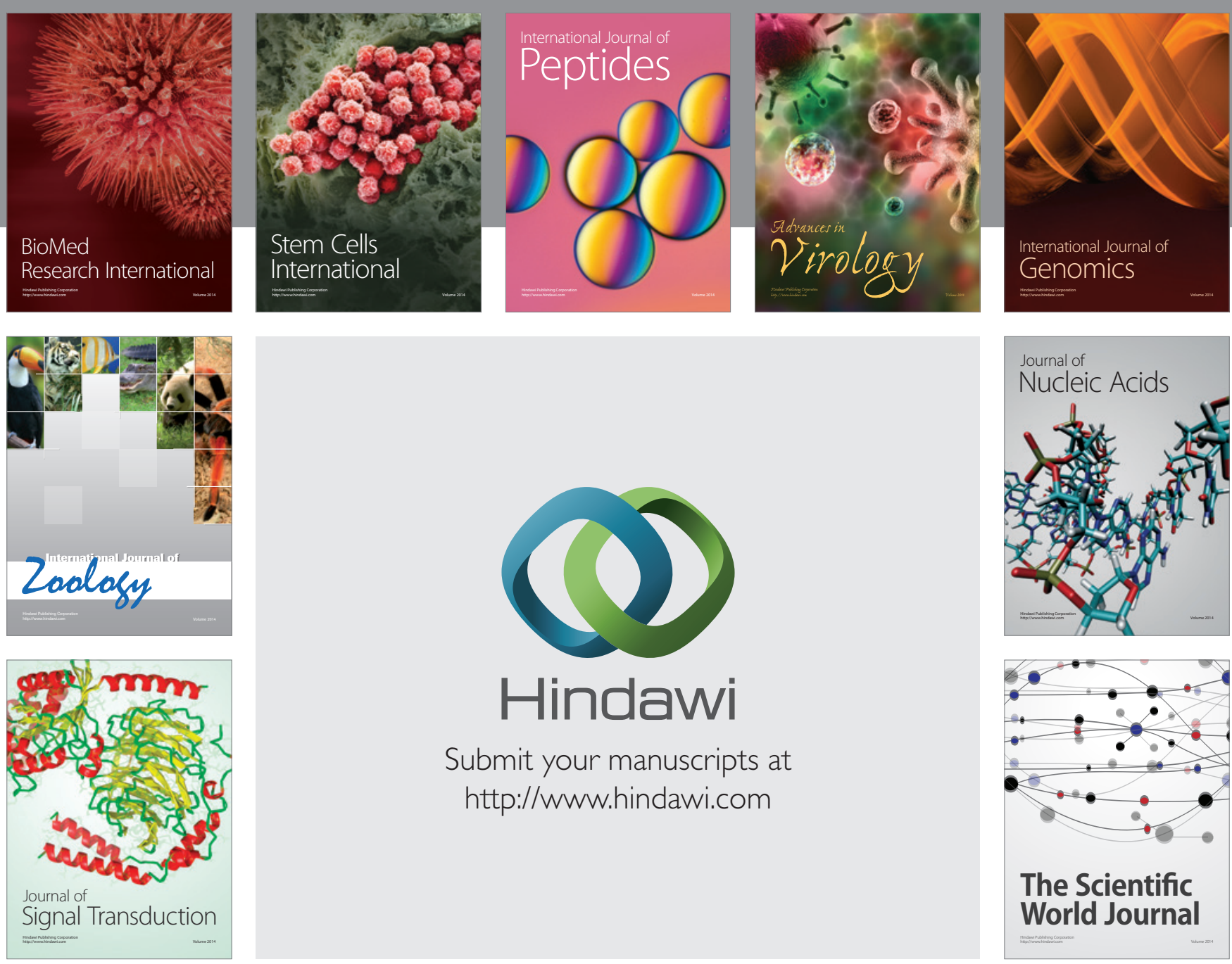

Submit your manuscripts at

http://www.hindawi.com
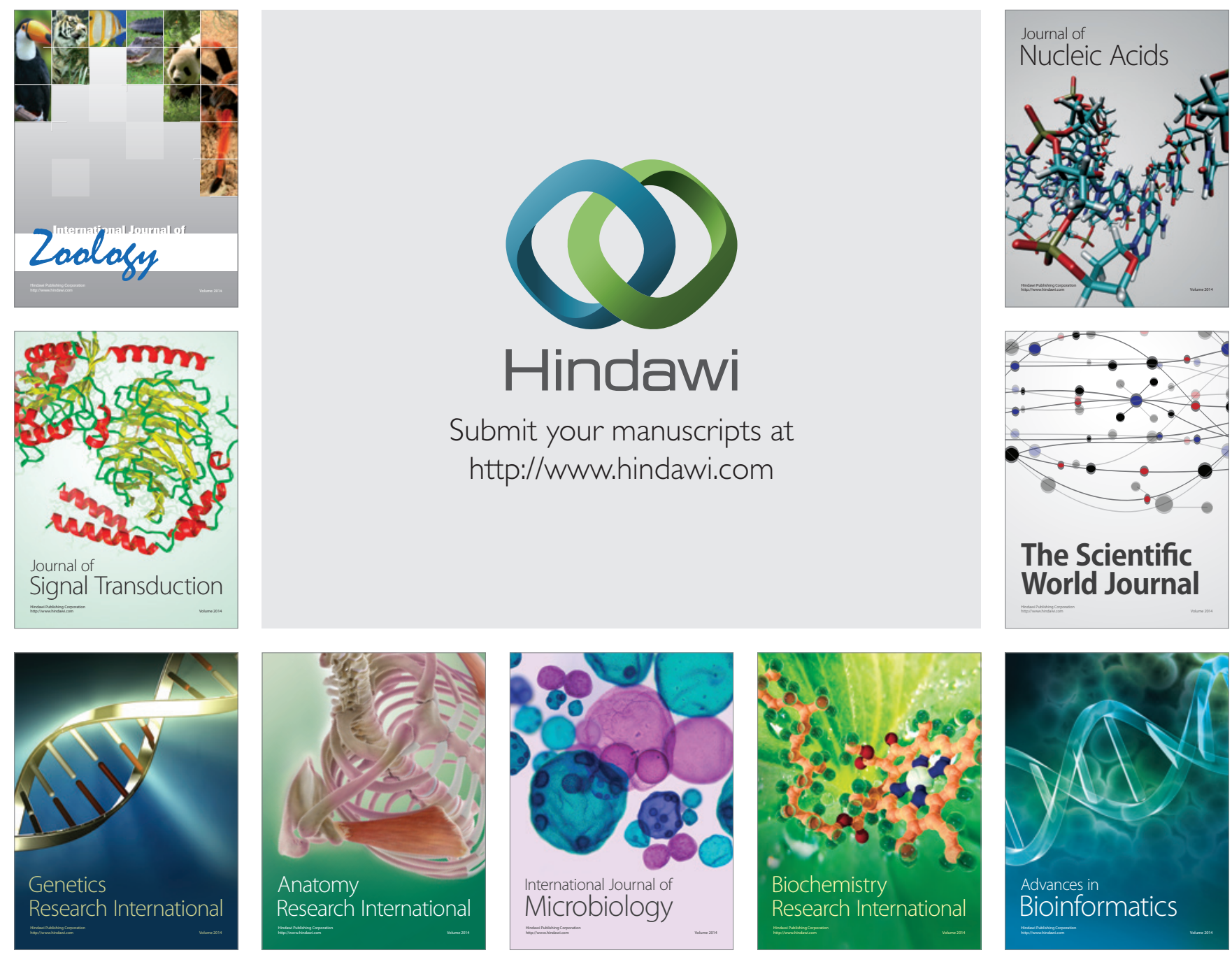

The Scientific World Journal
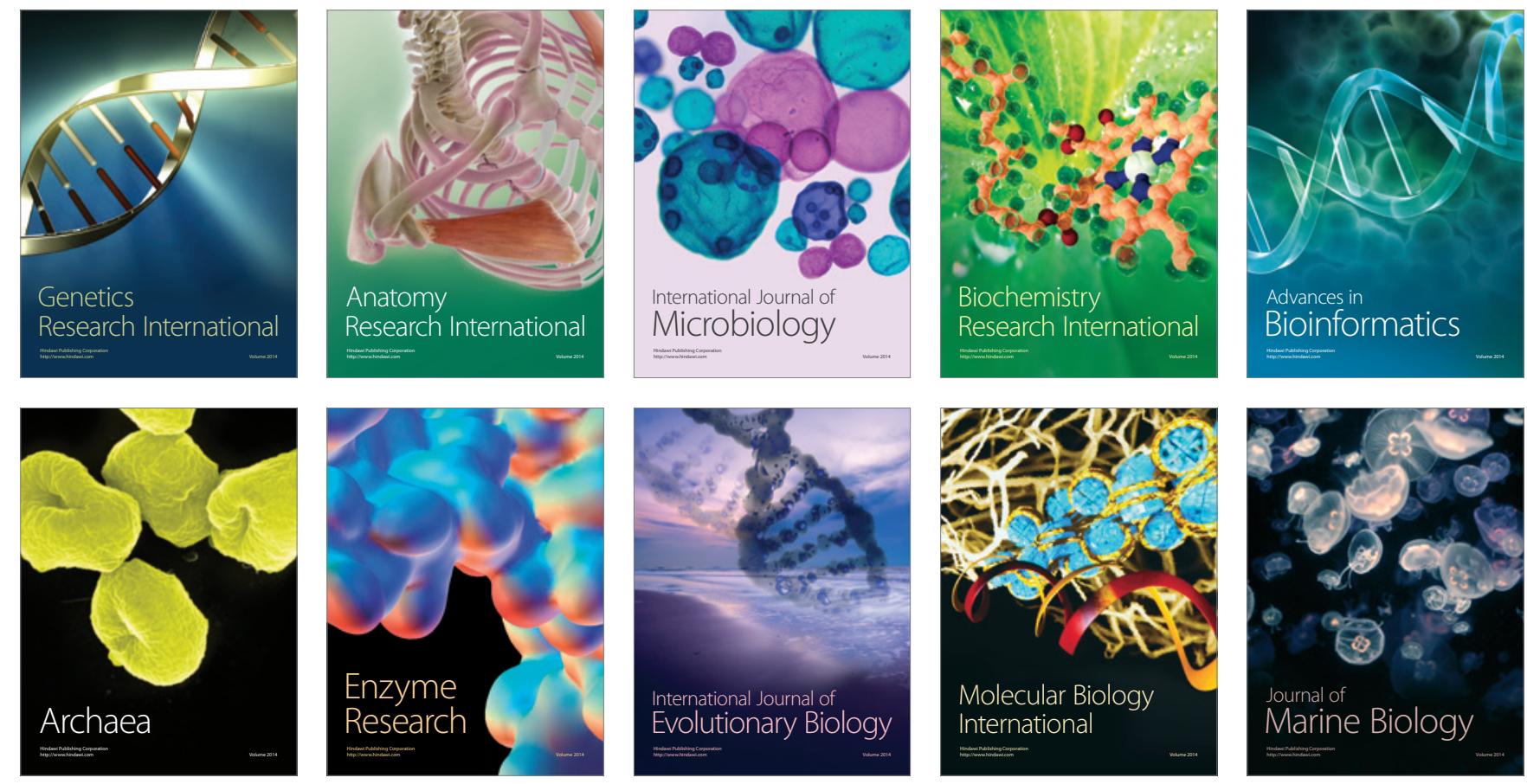